\title{
Multipotent Mesenchymal Stromal Cells Derived from the Bone Marrow Transported Over 12 Hours Change Their Main Characteristics
}

Petinati NA ${ }^{1}$, Shipounova $\mathrm{IN}^{1}$, Popova $\mathrm{MD}^{2}$, Drize $\mathrm{NJ}^{1 *}$, Kuzmina $\mathrm{LA}^{1}$, Parovichnikova EN ${ }^{1}$, Savchenko VG $^{1}$

${ }^{1}$ Federal Government Budget Institution National Research Center for Hematology, Ministry of Health, Moscow, Russia.

${ }^{2}$ Faculty of Biology, Department of Molecular Immunology, Moscow State University, Russia.

\section{*Corresponding Author:}

Drize Nina J,

FGBI National Research Center for Hematology, ZykovskiyNovyy pr., 4, Moscow, 125167, Russia.

Tel: $+7(903) 7959476$

Fax: +7(495)6120636

Email: ndrize@yandex.ru

Received: July 16, 2015

Accepted: August 05, 2015

Published: August 11, 2015

Citation: Drize NJ et al., (2015) Multipotent Mesenchymal Stromal Cells Derived from the Bone Marrow Transported Over 12 Hours Change Their Main Characteristics. Int J Stem Cell Res Transplant 03(4), 118-119. doi: http:/ / dx.doi.org/10.19070/2328-3548-1500019

Copyright: Drize $\mathbf{N J}^{\odot}$ 2015. This is an open-access article distributed under the terms of the Creative Commons Attribution License, which permits unrestricted use, distribution and reproduction in any medium, provided the original author and source are credited.

Many investigations have addressed the possibility of using multipotent mesenchymal stromal cells (MSCs) for treatment of various diseases due to their ability for tissue regeneration and unique immunomodulating capacities [1-3]. These stromal cells can be cultivated in vitro and represent adult, fibroblast-like cells that can differentiate into tissues of mesodermal origin [4]. Previous studies have attempted to develop the criteria for human MSC eligibility for therapeutic applications [5]. MSCs secrete various cytokines, growth factors and extracellular matrix molecules [4].

A randomized clinicaltrial (ClinicalTrials.gov NCT01941394) of MSCs application for graft versus host disease (GVHD) prophylaxis after allogeneic bone marrow transplantation has been on- going at the National Research Center for Hematology since 2008 [6]. The trial was approved by a local ethical committee, and informed consent from donors and patients has been obtained according to the Helsinki Declaration. All donor derived MSCs (113 samples) characteristics such as cumulative cell production and relative expression level (REL) of several genes were routinely analyzed. MSCs were cultivated from bone marrow and analyzed as described [7]. Twelve of the bone marrow samples were obtained from unrelated donors. These samples had been transferred to the National Research Center for Hematology at recommended conditions at $4^{\circ} \mathrm{C}[8]$, a process that required more than 12 hours, usually 14-30 hours. The cumulative cell production of MSCs derived from these samples $(\mathrm{N}=12)$ was significantly decreased in comparison with MSCs derived from not transported (fresh, $\mathrm{N}=101)$ bone marrow, $(5.1 \pm 0.6) \times 10^{6}$ and $(8.0 \pm 0.9) \times 10^{6} \mathrm{per}$ flask for 3 passages, respectively $(p<0.01)$. Dramatic changes in the REL of 7 genes were revealed in MSCs developed from transported bone marrow (Figure). The REL of CSF1, FGFR1 and PDGFRB decreased more than 3-fold ( $p<0.0001$ ), while those of VEGF, ICAM1 and VCAM1 decreased more than 2-fold $(p<0.05)$. The REL of FGFR2 increased 2 -fold $(p<0.01)$. The observed decline in MSC production may be due to the decreased REL of growth factor and receptor genes. Increased expression of FGFR2 did not affect the production of MSCs and possibly was compensatory. Moreover, the concentration of colonyforming units fibroblast (CFU-F) in the bone marrow samples that had been transported dramatically decreased to $1.83 \pm 0.76$ per $10^{6}$ bone marrow cells $(p<0.0001)$ compared with samples from fresh bone marrow $(27.0 \pm 2.8)$. The CFU-F concentration was found to be associated with the MSC growth parameters. The data suggests the decreased growth capacity of MSCs derived from transported bone marrow. At the same time no changes in REL of immunomodulating genes were revealed, that implies

Figure. REL of genes significantly altered in MSCs derived from transported bone marrow samples in comparison with MSCs derived from fresh bone marrow samples.

Relative Expression level of genes whose expression significantly changed in MSC after transportation

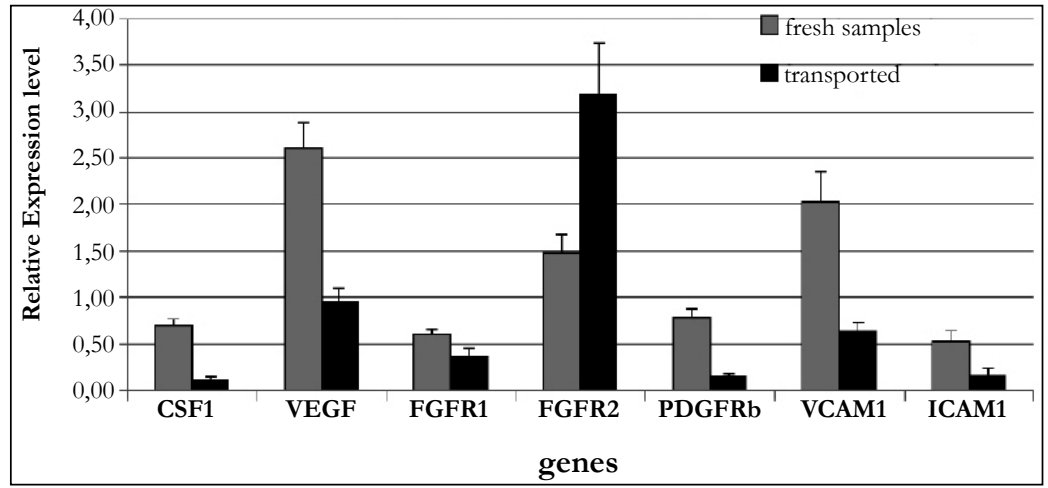


that such MSCs may be applicable for GVHD prophylaxis.

Possible changes in the MSC growth characteristics should be considered for MSCs derived from bone marrow after more than 12 hours of transportation.

\section{References}

[1]. Mariani E, Facchini A ( 2012) Clinical Applications and Biosafety of Human Adult Mesenchymal Stem Cells. Curr Pharm Des 18(3): 1821-1845.

[2]. Ren G, Chen X, Dong F, Li W, Ren X, et al. (2012) Concise review: mesenchymal stem cells and translational medicine: emerging issues. Stem Cells Transl Med 1(5): 51-58.

[3]. Jones BJ, McTaggart SJ (2008) Immunosuppression by mesenchymal stromal cells: from culture to clinic. Exp Hematol 36(6): 733-741.

[4]. Deans RJ, Moseley AB (2000) Mesenchymal stem cells: biology and poten- tial clinical uses. Exp Hematol 28(8): 875-884.

[5]. Samsonraj RM, Rai B, Sathiyanathan P, Puan KJ, Rötzschke O, et al. (2015) Establishing criteria for human mesenchymal stem cell potency. Stem Cells 33(6): 1878-1891.

[6]. Kuzmina LA, Petinati NA, Parovichnikova EN, Lubimova LS, Gribanova EO, et al. (2012) Multipotent Mesenchymal Stromal Cells for the Prophylaxis of Acute Graft-versus-Host Disease-A Phase II Study. Stem Cells Int 2012: 968213.

[7]. Shipounova IN, Petinati NA, Bigildeev AE, Sats NV, Drize NJ, et al. (2013) Hierarchy of mesenchymal stem cells: Comparison of multipotentmesenchymal stromal cells with fibroblast colony forming units. J Biomed Sci Eng 6(8): 66-73.

[8]. Cleaver SA, Warren P, Kern M, Hurley CK, Raffoux C, et al. (1997) Donor work-up and transport of bone marrow--recommendations and requirements for a standardized practice throughout the world from the Donor Registries and Quality Assurance Working Groups of the World Marrow Donor Association (WMDA). Bone Marrow Transplant 20(8): 621-629. 